\title{
PROPAGATION OF DRACAENA UMBRACULIFERA PLANT BY TISSUE CULTURE TECHNIQUE
}

\author{
A.W. Sayed \\ Ornamental Plants and Landscape Gardening Res. Dept., Hort. Res. Inst., ARC, Giza, Egypt
}

\begin{abstract}
An experiment was conducted at the Tissue Culture Laboratory of Al-Zohriya Garden, Hort. Res. Inst., ARC, Giza, Egypt during 2018 and 2019 seasons, with the aim to determine the best protocol of tissue culture technology to propagate Dracaena umbraculifera plant. For the possibility of spreading its cultivation to preserve it from extinction. As this plant is found in very few numbers, and it is difficult to form seeds under the climatic conditions in Egypt. Results obtained stated that using Clorox at 40\% for 20 min gave the highest significant survival percentage $(86.13 \%)$. For multiplication stage, benzyl adenine (BA) proved its superiority over kinetin in the production of a greater number and length of shoots. The highest number of shoots (3.20) was obtained with BA at $1.5 \mathrm{ppm}$ and the highest shoots length $(2.23 \mathrm{~cm})$ was recorded with $\mathrm{BA}$ at 1.3 $\mathrm{ppm}$. For rooting stage, the use of 1-naphthaleneacetic acid (NAA) at $0.3 \mathrm{ppm}$ produced the highest values of roots number/plantlet (3.13) and root length $(5.93 \mathrm{~cm})$, while the lowest values were recorded when using indole-3-butyric acid (IBA) at $0.1 \mathrm{ppm}$. For acclimatization stage, the type of pot media had a significant effect. Using peat moss only under greenhouse condition gave the highest survival percentage $(100 \%)$ and the highest values for all the measurements such as plant height $(\mathrm{cm})$, number of leaves/plant, root length $(\mathrm{cm})$, number of roots/plant, fresh and dry weights of leaves and roots (g/plant). Likewise, for the content of the leaves of total chlorophyll, carotenoids and the percentage of total soluble sugars. So, it can be recommended to make a protocol by using the tissue culture technique for propagating of Dracaena umbraculifera plant as follows: use Clorox at $40 \%$ for explant sterilization, using $1.5 \mathrm{ppm}$ of $\mathrm{BA}$ in the multiplication stage, using $0.3 \mathrm{ppm}$ of NAA in the rooting stage and using peat moss only to grow dracaena plant in the acclimatization stage to get plants with good growth characteristics.
\end{abstract}

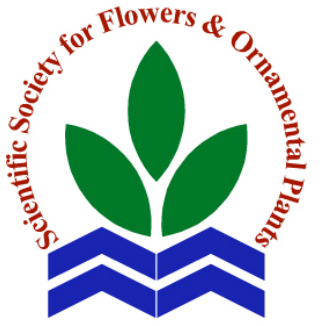

Scientific J. Flowers \& Ornamental Plants, 8(2):279-290 (2021).

Received:

27/5/2021

Accepted:

$13 / 6 / 2021$

Corresponding author: A.W. Sayed drahmedwahba50@yahoo.com

Key words: Dracaena umbraculifera, Clorox, survival percentage, BA, Kin, IBA, NAA, peat moss.

\section{INTRODUCTION}

Dracaena is a genus of some 60 species, many of which are used as ornamental plants. Dracaena umbraculifera is a rather rare species, and conservation measures are necessary to ensure its continued existence. It is an evergreen perennial plant, grows in a solitary trunk with a compact and nice arching leaves which can be $150 \mathrm{~cm}$ in length. Dracaena umbraculifera, Jacq. Arborescent (3-10 ft high), simple leaves very numerous, crowded, sword-shaped (2$\left.3 \frac{1}{2} \mathrm{ft} \times 1 \frac{1}{2}-2 \mathrm{in}\right)$, outer recurved, all green and shining, attenuate at the apex, scarcely narrowed toward the conspicuously undulate base, costa distinct on both faces: pedicels 46 lines long: bracts minute, deltoid: perianth large, 2 in long, white, tinged with red; filaments filiform. (Bailey, 1933). 


\section{A.W. Sayed}

D. umbraculifera is unique in having a very large umbrella of flowers "umbellate inflorescences," all flowers are born on stalks that originate at a single point. Flowers on outside are violet at early stage, then white inside when it blooms, attached on top of the crown. In general, this Dracaena flowers every 3-5 years or even more. It blooms in the winter and the flowers are scented, the color of the flowers is medium blue, bluish-violet, or white. Fruits are dark green, tightly held to the top, about the size of a marble. It needs to be planted in soil to have a nice and healthy plant. Water needs are average. It can be grown as an annual and needs full sun or partial shade. Seed germinations took about 50 days, Dave's Garden (2008). Dracaena umbraculifera belongs to the family Asparagaceae (James et al., 2016). Dracaena umbraculifera was described in 1797 from a cultivated plant attributed to Mauritius, it and it was categorized as Extinct on the IUCN Red List. Phylogenies indicated that D. umbraculifera is more closely related to Dracaena reflexa from Madagascar than to Mauritian Dracaena (Edwards et al., 2018).

\section{MATERIALS AND METHODS}

Dracaena umbraculifera is an evergreen ornamental plant rare that tolerates difficult and conditions. Therefore, this study was carried out in the Tissue Culture Laboratory of Al-Zohriya Garden, Horticulture Research Institute, Agricultural Research Center, Giza, Egypt during the period from 2018 and 2019 to establish an applicable protocol for the rapid micropropagation of Dracaena umbraculifera, for the possibility of spreading its cultivation and protecting it from extinction. As this plant is found in very few numbers, and it is difficult to form seeds under the climatic conditions in Egypt.

\section{Explant source and preparation:}

Terminal buds of Dracaena umbraculifera were taken from plants grown in Al-Zohriya Garden, and was moved to the tissue culture lab where they were cleaned washed with running water thoroughly. Then washed up by liquid soap and washed again with running water to rid them of surface contaminants as much as possible.

\section{Glassware:}

Glass jars of $11.5 \mathrm{~cm}$ height $\times 6.5 \mathrm{~cm}$ diameter with their polypropylene caps were used during establishment, multiplication and rooting stages. In order to avoid contamination problems, jars were washed then soaked in a detergent solution for 24 hours, sterilized with $10 \%$ solution of sodium hypochlorite for 2 hours, rinsed with distilled water and autoclaved at $1.05 \mathrm{~kg} / \mathrm{cm}^{2}$ and $121{ }^{\circ} \mathrm{C}$ for $25 \mathrm{~min}$ before being filled with $40 \mathrm{ml}$ of the MS medium/jar.

\section{Culture medium:}

MS medium (Murashige and Skoog, 1962) was used. This medium contained, in addition to the prescribed salts and vitamins, $20 \mathrm{~g} / 1$ sucrose and $6 \mathrm{~g} / \mathrm{l}$ agar. It was adjusted to $5.8 \mathrm{pH}$, poured in the jars and autoclaved at $121{ }^{\circ} \mathrm{C}$ for 20 minutes under $1.05 \mathrm{~kg} / \mathrm{cm}^{2}$ pressure, left to cool and stored at $25 \pm 2{ }^{\circ} \mathrm{C}$ for one week before being used.

\section{Experiment 1 (sterilization stage):}

Determination of the best concentration of Clorox (commercial bleach) solution, was the aim of this experiment. Surface sterilization of explants (buds) was carried out under hood, using different concentrations of Clorox, i.e. 0.0, 20, 30, 40 and $50 \%$, for $20 \mathrm{~min}$. Buds were then rinsed with sterilized distilled water before being inoculated on MS medium at 3 quarters strength, free of any growth regulators under aseptic conditions. Jars were incubated at $25 \pm 2{ }^{\circ} \mathrm{C}$ (day/night) and $70 \%$ relative humidity. Two fluorescent tubes/shelf were installed at $30 \mathrm{~cm}$ above explants to provide light intensity of 3000 lux at explants level for 16 hour a day (Prasanth and Sekar, 2004). Total number of treatments was five, each treatment comprised 5 replicates, each replicate contained 3 jars with 1 explant/jar. In this experiment the percentage of survival was recorded three weeks later. This percentage represents the explants that survived and were free of contamination. 


\section{Experiment 2 (multiplication stage):}

The second experiment was carried out to compare the effect of two types of cytokinins at different levels on explants inoculated on MS medium in the multiplication stage. Accordingly, treatments comprising either Benzyl adenine (BA) or kinetin (Kin), each at 4 concentrations (0.0, 1.3, 1.4 and $1.5 \mathrm{ppm}$ ). Data recorded 45 days later were number of shoots/explant and shoot length $(\mathrm{cm})$.

\section{Experiment 3 (rooting stage):}

Shoots resulting from the previous stage were used. Two types of auxins (indole-3butyric acid and 1-naphthaleneacetic acid) each at $0.0,0.1,0.2$ and $0.3 \mathrm{ppm}$ were used. After 45 days the following data were recorded: number of roots/plantlet and root length $(\mathrm{cm})$.

\section{Experiment 4 (acclimatization stage):}

Plantlets resulting from the previous stage were adapted outside the laboratory. Plantlets were pricked out and separately planted into $10 \mathrm{~cm}$ plastic pots filled with two types of cultivation medium, peat moos only and peat moss + sand mixture $(1: 1, \mathrm{v} / \mathrm{v})$. Pots were covered with clear transparent plastic sheets for three weeks to keep a high degree of humidity. Afterwards, these plastic covers were removed gradually to reduce humidity and to adapt the plantlets in greenhouse conditions.
After one month planting, the survival percentage was recorded, then the plantlets were transferred to $20 \mathrm{~cm}$ plastic pots filled with the same cultivation environments mentioned above. Then after two months from planting the data were recorded as follows: plant height $(\mathrm{cm})$, number of leaves/plant, root length $(\mathrm{cm})$ and number of roots/plant, as well as leaves and roots fresh and dry weights (g/plant).

In the fresh leaf samples taken from the middle parts of plants, the content of photosynthetic pigments (total chlorophylls $(a+b)$ and carotenoids mg/g f.w.) and the percent of total soluble sugars were determined according to the methods of Sumanta et al. (2014) and Dubois et al. (1966), respectively. Tables (a) and (b) show some characteristics of sand and peat moss.

All experiments were laid out in a complete randomized design (Mead et al., 1993). To statistically test results of these experiments, analysis of variance was carried out, as described by SAS Institute (2009). The means were compared by Duncan critical range at a probability level of $5 \%$ (Steel and Torrie, 1980).

\section{RESULTS AND DISCUSSION}

\section{Sterilization Stage:}

Data presented in Table (1) and Fig. (1) indicated that Clorox concentration had a significant effect on survival rate percentage

Table a. Some physical and chemical properties of peat moss used in this study.

\begin{tabular}{llll}
\hline Organic matter (\%) & $90-95$ & $\mathbf{P}(\%)$ & 0.23 \\
Ash (\%) & $8-10$ & $\mathbf{K}(\%)$ & 1.77 \\
Density (vol. dry; mg/l) & $80-90$ & $\mathbf{F e}(\mathbf{p p m})$ & 421 \\
pH value & 3.4 & $\mathbf{M n}(\mathbf{p p m})$ & 27 \\
Water relation capacity (\%) & $60-75$ & $\mathbf{Z n}(\mathbf{p p m})$ & 41 \\
Salinity (g/l) & 0.3 & $\mathbf{C u}(\mathbf{p p m})$ & 8.8 \\
$\mathbf{N}(\%)$ & 1.09 & $\mathbf{M g}(\mathbf{p p m})$ & 33 \\
\hline
\end{tabular}

Table b. The physical and chemical analysis of potting mixture used in this study.

\begin{tabular}{|c|c|c|c|c|c|c|c|c|c|c|c|c|c|}
\hline \multicolumn{4}{|l|}{ Parti } & \multirow[b]{2}{*}{ S.P } & \multirow{2}{*}{$\begin{array}{c}\text { E.C. } \\
(\mathrm{dS} / \mathrm{m})\end{array}$} & \multirow{2}{*}{ pI } & \multicolumn{4}{|c|}{ Catio } & \multicolumn{3}{|c|}{ ns ( } \\
\hline & ine & & & & & & & & & & & $\mathrm{Cl}^{-}$ & \\
\hline 5.2 & (1) & .50 & 6.23 & 2.8 & 41 & 1.0 & 15.42 & 9.30 & 10.15 & 0.8 & 1.50 & 11.90 & 22.30 \\
\hline
\end{tabular}




\section{A.W. Sayed}

Table 1. Effect of different concentrations of Clorox on explants survival\% of Dracaena umbraculifera plant.

\begin{tabular}{lc}
\hline Clorox concentration (\%) & Survival \% \\
\hline $\mathbf{0 . 0}$ & $00.00 \mathrm{c}$ \\
$\mathbf{2 0}$ & $00.00 \mathrm{c}$ \\
$\mathbf{3 0}$ & $12.57 \mathrm{~b}$ \\
$\mathbf{4 0}$ & $86.13 \mathrm{a}$ \\
$\mathbf{5 0}$ & $00.00 \mathrm{c}$ \\
\hline
\end{tabular}

Means within a column having the same letters are not significantly different according to Duncan's New Multiple Range t-Test at 5\% level.

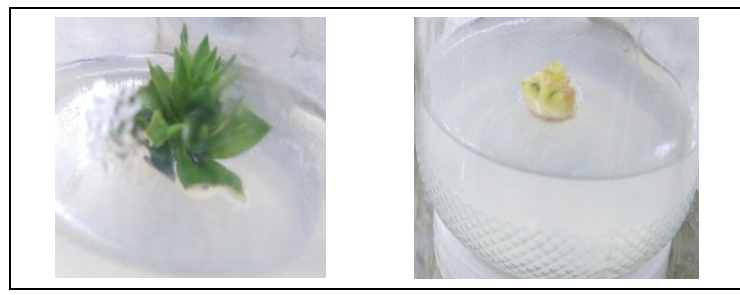

Fig. 1. Effect of Clorox concentration at $40 \%$ on Dracaena umbraculifera buds.

of Dracaena umbraculifera explants. However, using Clorox at either 20 or $30 \%$ was not enough to prevent contamination, diminishing survival percentage to (zero and $12.57 \%$ ), respectively. By increase the concentration of Clorox at $40 \%$, survival rate percentage rose to the highest level $(86.13$ $\%$ ) compared to the control. While, increase in Clorox concentration at $50 \%$ exerted a detrimental effect on survival rate percentage, lowering it to zero.

Our results are in accordance with most findings of many authors, as shown in the following discussion:

Surface sterilization of the plant material plays a very important role in the tissue process. Lizarraga et al. (1986) and Dodds and Roberts (1995) stated that the surface sterilization of plant material may be accomplished with an aqueous solution of sodium hypochlorite. Although Sagripanti and Bonifacino (1999) suggested that commercial liquid sterilants and disinfectants including Clorox are less effective on contaminated surfaces than generally acknowledged. Warakagoda et al. (2007) revealed that $25 \%$ Clorox for 20 min was the best surface sterilization procedure for axillary buds of sugarcane. El-Shamy et al. (2009) on Gerbera jamesonii emphasized that using 30\% Clorox for $15 \mathrm{~min}$ and $30 \%$ Clorox for $10-20 \mathrm{~min}$, respectively for sterilization of explants gave the best result of $(100 \%)$ survival and free of contamination of leaf and seeds explants. Omira et al. (2011) found that in order to optimize the establishment of in vitro cultures of Anthurium andraeamum shoot tips from adult greenhouse plants, should be surface sterilized by Clorox solution. They found that using Clorox (commercial bleach contaning sodium hypochlorite 5\%) at $30 \%$ for $20 \mathrm{~min}$, no contaminated or dead explants was observed. Sharifkhani et al. (2011) revealed a significant relationship between the sodium hypochlorite concentration and percentage of surviving explants of Aloe vera barbadensis. Sakr et al. (2011) reported that surface sterilization with $20 \%$ Clorox gave the best result of survival for shoot tips and axillary buds of Cerbera odollam (Apocynaceae). Dar et al. (2012) stated that the optimized sterilization conditions for Hibiscus rosa-sinensis node explants were $40 \%$ Clorox for 20 min exposure. Dar et al. (2012) on Hibiscus rosa-sinensis stated that the optimium sterilization conditions for explants were $40 \%$ Clorox- 20 min exposure, $10 \%$ Clorox-15 min exposure, and 5\% Clorox-40 min exposure for the node, internode and shoot tip, respectively. Abd Alla et al. (2013) treated stem nodes of cassava (Manihot esculenta), with different concentrations of Clorox (10, 20 and 30\%). They found that the lowest significant contamination and the highest significant survival percentages were recorded with 20\% Clorox. Khafagy et al. (2013) found that on Amphilophium paniculatum, using Clorox at $20-25 \%$ in sterilization recorded the highest significant survival\%. El-Afry et al. (2017) found that using Clorox at 35\% for 25 minutes gave the highest percentage of survival of Phytolacca dioica buds. Ghareeb and Taha (2018) found that the 
highest percent of aseptic cultures and survival of Antigonon leptopus explants were obtained as a result of using Clorox 20\% which caused the highest percent of shoot formation.

\section{Multiplication Stage:}

The effect of cytokinin type and concentration as well as their interaction on number of shoots and shoot length of Dracaena umbraculifera are shown in Table (2) and Fig. (2). It is clear from the presented data that the cytokinin type affected number of shoots and shoot length compared to the control. BA concentration had significant effect on number of shoots and shoot length. Using $\mathrm{BA}$ at $1.5 \mathrm{ppm}$ gave the highest number of shoots (3.20 shoots). Increasing BA level from 1.3 to $1.4 \mathrm{ppm}$ led to an increase in number of shoots from 1.40 to 1.93 shoots, respectively. These results agreed with Tawfik et al. 2020 who reported that increasing BAP concentration up to 1.5 $\mathrm{mg} / \mathrm{l}$ increased all the measurement parameters of nodal explants taken from the germinated seedlings of Koelreuteria bipinnata. Nodal segments gave the highest shoot number (2.5 shoots/explant), shoot length $(4 \mathrm{~cm})$ and leaves number (5 leaves/shoot) when cultured on MS medium supplemented with $1.5 \mathrm{mg} / \mathrm{l}$ BAP.

On the contrary the highest value of shoot length $(2.23 \mathrm{~cm})$ was recorded with $\mathrm{BA}$ at $1.3 \mathrm{ppm}$ was applied compared to the control treatment. While regarding Kin concentration, data showed that Kin concentration at $1.3 \mathrm{ppm}$ had no significant effect on number of shoots and shoot length . While, increase in Kin concentration to 1.4 or $1.5 \mathrm{ppm}$ exerted a detrimental effect, cut them down to zero.

The interaction between BA and Kin was significant in increasing number of shoots. BA at $1.5 \mathrm{ppm}$ in addition to Kin at $1.5 \mathrm{ppm}$ were the best for inducing greater number of shoots (1.60 shoots). Similar results were stated by Tawfik et al. (2018). They reported that the interaction between BAP at $1 \mathrm{mg} / 1$ plus kinetin at $0.5 \mathrm{mg} / 1$ gave

Table 2. Effect of cytokinin type, concentration and their interaction on number of shoots and shoot length of Dracaena umbraculifera plant.

\begin{tabular}{|c|c|c|c|c|c|c|}
\hline \multirow{3}{*}{ Cytokinin concentration } & \multicolumn{3}{|c|}{ No. of shoots/explant } & \multicolumn{3}{|c|}{ Shoot length $(\mathrm{cm})$} \\
\hline & \multicolumn{6}{|c|}{ Cytokinin type } \\
\hline & $\mathbf{B A}$ & Kin & Mean & BA & Kin & Mean \\
\hline $0.0 \mathrm{ppm}$ & $1.00 \mathrm{~d}$ & $1.00 \mathrm{~d}$ & $1.00 \mathrm{c}$ & $2.13 \mathrm{~b}$ & $2.13 \mathrm{~b}$ & $2.13 \mathrm{a}$ \\
\hline $1.3 \mathrm{ppm}$ & $1.40 \mathrm{c}$ & $1.00 \mathrm{~d}$ & $1.20 \mathrm{~b}$ & $2.23 \mathrm{a}$ & $2.13 \mathrm{~b}$ & $2.18 \mathrm{a}$ \\
\hline 1.4 ppm & $1.93 \mathrm{~b}$ & $0.00 \mathrm{e}$ & $0.97 \mathrm{c}$ & $1.93 \mathrm{c}$ & $0.00 \mathrm{e}$ & $0.97 \mathrm{~b}$ \\
\hline 1.5 ppm & $3.20 \mathrm{a}$ & $0.00 \mathrm{e}$ & $1.60 \mathrm{a}$ & $1.70 \mathrm{~d}$ & $0.00 \mathrm{e}$ & $0.85 \mathrm{~b}$ \\
\hline Mean & $1.88 \mathrm{a}$ & $0.50 \mathrm{~b}$ & & $2.00 \mathrm{a}$ & $1.07 \mathrm{~b}$ & \\
\hline
\end{tabular}

Means within a column or row having the same letters are not significantly different according to Duncan's New Multiple Range t-Test at 5\% level.

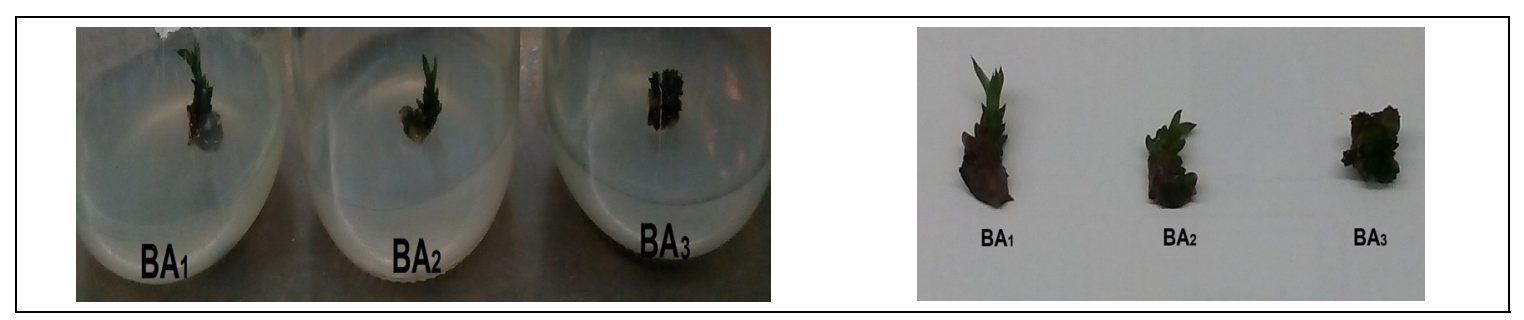

Fig. 2. Effect of BA treatments on Dracaena umbraculifera. Treatments from left to right: cytokinin concentration (1) at $1.3,(2)$ at 1.4 and (3) at $1.5 \mathrm{ppm}$ for each. 


\section{A.W. Sayed}

the highest shoot number/explant (4 shoots) of Rosa spp cv. Eiffel Tower. On the contrary, the interaction between BA and Kin was not significant in increasing shoot length. The highest level of BA and Kin (1.5 $\mathrm{ppm}$ for each) gave the lowest value $(0.85$ $\mathrm{cm})$.

Sayed et al. (2009) recorded that the higher number of branches resulted with in media provided with BAP at $1 \mathrm{ppm}$, while media devoid of cytokinins (control treatment) produced the significantly lowest number of branches on Clerodendrum glabrum and Mussaenda luteola. They also found that the largest number of leaves resulted on Mussaenda luteola branches treated with BAP at $3 \mathrm{ppm}$. Aslam et al. (2013) on Dracaena sanderiana declared that the highest frequency of shoot regeneration and number of shoots per explant were obtained on medium supplemented with $1.77 \mathrm{ppm}$ BA. Khafagy et al. (2013) found that on Amphilophium paniculatum, in the multiplication stage, the highest number of shoots and leaves with BA at 4 ppm. Tyagi and Tomar (2013) on Tecomella undulata concluded that shoots produced the greatest shoot length and shoot number when cultured on MS medium +1 ppm BA. Chen et al. (2014) on Agave americana found that the highest number of shoots was obtained on a modified Murashige and Skoog medium (MSI) supplemented with 3 ppm BA. Kikowska et al. (2014) on Eryngium maritimum reported that the highest plant regeneration efficiency was induced on MS medium supplemented with $1.0 \mathrm{ppm}$ BA and $0.1 \mathrm{ppm}$ IAA. Kirika et al. (2015) on Erythrina abyssinica stated that BA at $8.61 \mathrm{mg} / \mathrm{l}$ gave the highest number of microshoots. Silveira et al. (2016) on Calophyllum brasiliense reported that for shoot multiplication, BA was used in concentrations of 1 and $2 \mathrm{ppm}$ in Woody Plant Medium, resulting in an average of 4.43 and 4.68 shoots per explant, respectively. Sarhan et al. (2017) reported that using BAP at $0.60 \mathrm{ppm}+1 / 2 \mathrm{MS}$ medium it gave the highest results of lateral buds survival \%, regeneration capacity, culture efficiency, shoot number, shoot length and leaf number of Porana paniculata. Dewir et al. (2018) on Conocarpus erectus found that the type and concentration of applied cytokinins had a significant effect on shoot proliferation responses, and supplementation with BAP increased the rate of shoot proliferation compared with other cytokinins. Juras et al. (2019) on Cattleya xanthina showed that a higher concentration of cytokinin $(0.50 \mathrm{ppm}$ BA) promoted protein synthesis and the development of shoots. Ghareeb and Taha (2018) found that during the multiplication stage of Antigonon leptopus explants, the highest number of shootlets/explant were obtained when $1.0 \mathrm{mg} / 1$ of BAP was added to MS medium. Dewir et al. (2019) on Dracaena ombet mentioned that in vitro shoots cultured onto MS medium supplemented with 1-2 mg/l BAP and 0.5 $\mathrm{mg} / \mathrm{l}$ IBA resulted in the highest number of axillary shoots. Taha et al. (2019) mentioned that using MS medium supplemented with $\mathrm{BA}$ at $1.5 \mathrm{ppm}$ had a significant promotion effect on number of bulb scales/explant which can induce adventitious bulblet formation for micropropagation of the Asiatic hybrid lily 'Red Alert'. Alawaadh et al. (2020) on Philodendron bipinnatifidum stated that adding BAP at $1 \mathrm{mg} / \mathrm{l}$ significantly increased shoot multiplication compared with other cytokinins. Hassan and Moubarak (2020) declared that the results of MS medium supplemented with $1 \mathrm{mg} / \mathrm{l} \mathrm{BA}$ significantly outperformed other tested cytokinins, yucca shoot multiplication, and growth parameters (number of shoots and leaves/shoot, and shoot length).

\section{Rooting Stage:}

The effect of auxin type and concentration as well as their interaction on number of roots/plantlet and root length of Dracaena umbraculifera are shown in Table (3) and Fig. (3).

Data demonstrated that NAA significantly affected rooting stage. NAA was superior to IBA regarding number of roots/plantlet and root length $(\mathrm{cm})$. 
Table 3. Effect of auxins type, concentrations and their interaction on number of roots and root length of Dracaena umbraculifera plant.

No. of roots/plantlet

Root length (cm)

\begin{tabular}{lcccccc}
\hline \multirow{2}{*}{ Auxin concentration } & \multicolumn{3}{c}{ No. of roots/plantlet } & \multicolumn{4}{c}{ Root length (cm) } \\
& IBA & NAA & Mean & IBA & NAA & Mean \\
\hline $\mathbf{0 . 0} \mathbf{~ p p m}$ & $0.00 \mathrm{f}$ & $0.00 \mathrm{f}$ & $0.00 \mathrm{~d}$ & $0.00 \mathrm{f}$ & $0.00 \mathrm{f}$ & $0.00 \mathrm{~d}$ \\
$\mathbf{0 . 1} \mathbf{~ p p m}$ & $1.20 \mathrm{e}$ & $1.37 \mathrm{~d}$ & $1.29 \mathrm{c}$ & $3.20 \mathrm{e}$ & $3.43 \mathrm{~d}$ & $3.32 \mathrm{c}$ \\
$\mathbf{0 . 2} \mathbf{~ p p m}$ & $2.63 \mathrm{c}$ & $2.53 \mathrm{c}$ & $2.58 \mathrm{~b}$ & $4.77 \mathrm{c}$ & $5.33 \mathrm{~b}$ & $5.05 \mathrm{~b}$ \\
$\mathbf{0 . 3} \mathbf{~ p p m}$ & $2.87 \mathrm{~b}$ & $3.13 \mathrm{a}$ & $3.00 \mathrm{a}$ & $5.37 \mathrm{~b}$ & $5.93 \mathrm{a}$ & $5.65 \mathrm{a}$ \\
Mean & $1.68 \mathrm{a}$ & $1.76 \mathrm{a}$ & & $3.34 \mathrm{~b}$ & $3.67 \mathrm{a}$ & \\
\hline
\end{tabular}

Means within a column or row having the same letters are not significantly different according to Duncan's New Multiple Range t-Test at $5 \%$ level.

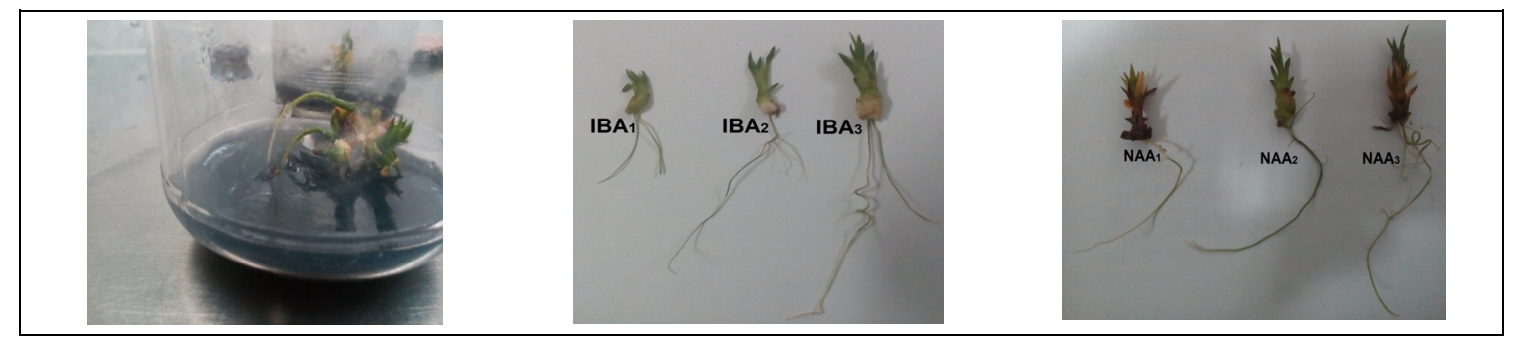

Fig. 3. Effect of IBA and NAA treatments on Dracaena umbraculifera. Treatments from left to right: auxins concentration (1) at $0.1,(2)$ at 0.2 and (3) at $0.3 \mathrm{ppm}$ for each.

Concerning NAA level, it was found that NAA at $0.3 \mathrm{ppm}$ gave the highest significant number of roots/plantlet and root length (3.13 roots and $5.93 \mathrm{~cm}$, respectively) compared to the control. Similarly for IBA level, it was noted that IBA at $0.3 \mathrm{ppm}$ gave the highest number of roots/plantlet and root length (2.87 roots and $5.37 \mathrm{~cm}$, respectively) compared to the control.

The interaction between IBA and NAA was significant in increasing number of roots and root length. NAA at $0.3 \mathrm{ppm}$ was the best for inducing greater number of roots/plantlet and root length (3.00 roots and $5.65 \mathrm{~cm}$, respectively) compared to the control. While IBA at $0.1 \mathrm{ppm}$ gave the lowest values (1.29 roots and $3.32 \mathrm{~cm}$, respectively).

El-Shamy et al. (2009) found that shoots of Gerbera jamesonii cv. aurantiaca were successfully rooted when cultured in MS medium supplemented with $1.5 \mathrm{mg} / \mathrm{l}$ IBA. Aslam et al. (2013) on Dracaena sanderiana declared that rooting was high on MS medium supplemented with $1.5 \mathrm{ppm}$ IBA. Khafagy et al. (2013) found that on Amphilophium paniculatum, the highest number of roots in the rooting stage was induced when IBA at 3 ppm was applied. Tyagi and Tomar (2013) on Tecomella undulata remarked that in vitro regenerated shoots rooted maximally by dip treatment for 15 minutes in a solution of NAA (100 ppm) and IBA $(100 \mathrm{ppm})$ followed by transfer on $1 / 2$ strength Gamborg (B5) basal medium. Chen et al. (2014) on Agave americana found that the highest rooting frequency and mean number of shoots occurred in Murashige and Skoog medium ( $1 / 2$ MS1) containing $1 \mathrm{ppm}$ IBA alone or $0.3 \mathrm{ppm}$ IBA plus 0.3 ppm NAA. Kirika et al. (2015) on Erythrina abyssinica stated that IBA at 0.51 $\mathrm{mg} / \mathrm{l}$ gave the longest roots. Silveira et al. (2016) on Calophyllum brasiliense reported that IBA and NAA were used to induce root formation. The maximum rooting rate was a result of using $3.72 \mathrm{ppm}$ NAA. Bakheet et 


\section{A.W. Sayed}

al. (2018) on Codiaeum variegatum in vitro found that the roots were successfully induced by 1 or $2 \mathrm{mg} / 1$ of IBA which gave longest and few roots, while $1 \mathrm{mg} / \mathrm{l}$ NAA gave shorter and more root number. Dewir et al. (2018) on Conocarpus erectus mentioned that the best rooting medium was MS supplemented with $1 \mathrm{mg} / \mathrm{l}$ IBA. Silvestri et al. (2018) on Lycium barbarum found that rooting of shoots was carried out in vitro with $0.5-1 \mathrm{mg} / 1$ of IBA. Dewir et al. (2019) on Dracaena ombet found that $100 \%$ rooting was obtained using half strength MS medium supplemented with 0.5 or $1 \mathrm{mg} / 1$ IBA. Juras et al. (2019) on Cattleya xanthina showed that the highest concentration of auxin (0.11 ppm NAA) stimulated root development and the production of photosynthetic pigments.

\section{Acclimatization Stage:}

\section{a. Survival rate percentage, vegetative and} root growth:

Plantlets of Dracaena umbraculifera were successfully transferred to pots filled with either peat moss only and a mixture of peat moss + sand $(1: 1, \mathrm{v} / \mathrm{v})$, respectively in the greenhouse. The survival of plantlets after one month was calculated and gave (100 and 95\%, respectively).

Table (4) and Fig. (4) showed that the effect of potting media after two months of planting was significant on plant height, number of leaves/plant, root length and number of roots. The highest values were recorded with the plants grown in (peat moos only) media.

\section{b. Leaves and roots fresh and dry weights:}

Data in Table (5) showed the effect of growing media on the leaves fresh and dry weights was significant. Using peat moss only as a potting medium resulted in the highest values fresh and dry of leaves (10.61 and $1.36 \mathrm{~g} /$ plant, respectively). Followed by potting medium of peat moss + sand mixture $(1: 1, \mathrm{v} / \mathrm{v})$ gave the lowest values $(2.37$ and $0.33 \mathrm{~g} /$ plant, respectively).

Likewise, the root fresh and dry weights were significantly influenced. Using peat moss only as a potting medium resulted in the highest values fresh and dry of roots (4.88 and $1.19 \mathrm{~g} /$ plant), respectively. While the plants grown in peat moss + sand mixture $(1: 1, \mathrm{v} / \mathrm{v})$ gave the lowest values (1.35 and $0.26 \mathrm{~g} /$ plant, respectively).

\section{c. Chemical composition in the leaves:}

Results in Table (6) revealed that the effect of growing media on photosynthetic pigments content (total chlorophyll and carotenoids) and the percentage of total soluble sugars were significantly. The highest content in this regard was recorded in leaves of plants grown on peat moss only $(0.737, \quad 0.280$ and $9.91 \mathrm{mg} / \mathrm{g}$ f.w.,

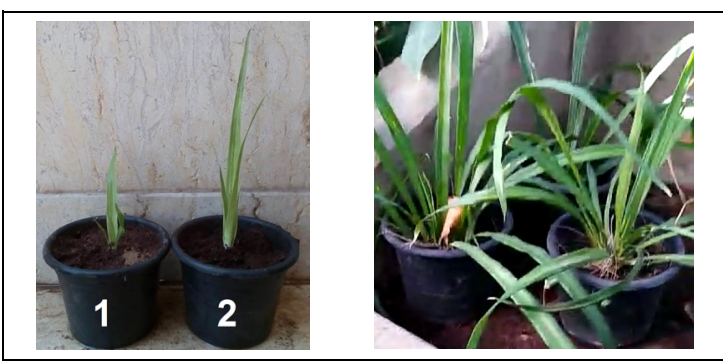

Fig. 4. Effect of different potting media on Dracaena umbraculifera treatments from left to right (1) peatmoss + sand mixture $(1: 1, \mathrm{v} / \mathrm{v}),(2)$ peatmoss only.

Table 4. Effect of growing media treatments on survival percentage, plant height, number of leaves/plant, root length and number of roots of Dracaena umbraculifera plant.

\begin{tabular}{lccccc}
\hline \multicolumn{1}{c}{ Treatments } & $\begin{array}{c}\text { Survival rate } \\
\mathbf{\%}\end{array}$ & $\begin{array}{c}\text { Plant length } \\
(\mathbf{c m})\end{array}$ & $\begin{array}{c}\text { No. of leaves/ } \\
\text { plant }\end{array}$ & $\begin{array}{c}\text { Root length } \\
(\mathbf{c m})\end{array}$ & $\begin{array}{c}\text { No. of root/ } \\
\text { plant }\end{array}$ \\
\hline Peat moss only & $100.00 \mathrm{a}$ & $29.33 \mathrm{a}$ & $5.67 \mathrm{a}$ & $22.67 \mathrm{a}$ & $21.67 \mathrm{a}$ \\
$\begin{array}{l}\text { Peat moss + sand mixture } \\
\text { v/v) }\end{array}$ & $95.00 \mathrm{~b}$ & $18.90 \mathrm{~b}$ & $3.67 \mathrm{~b}$ & $17.20 \mathrm{~b}$ & $13.33 \mathrm{~b}$ \\
\hline
\end{tabular}

Means within a column having the same letters are not significantly different according to Duncan's New Multiple Range t-Test at 5\% level. 
Table 5. Effect of growth medium treatments on leaves and roots fresh and dry weights of Dracaena umbraculifera plant.

\begin{tabular}{lcccc}
\hline \multirow{2}{*}{ Treatments } & \multicolumn{2}{c}{ Leaves (g/plant) } & \multicolumn{2}{c}{ Roots (g/plant) } \\
\cline { 2 - 5 } & Fresh weight & Dry weight & Fresh weight & Dry weight \\
\hline Peat moss only & $10.61 \mathrm{a}$ & $1.36 \mathrm{a}$ & $4.88 \mathrm{a}$ & $1.19 \mathrm{a}$ \\
$\begin{array}{l}\text { Peat moss + sand mixture (1:1, } \\
\text { v/v) }\end{array}$ & $2.37 \mathrm{~b}$ & $0.33 \mathrm{~b}$ & $1.35 \mathrm{~b}$ & $0.26 \mathrm{~b}$ \\
\hline
\end{tabular}

Means within a column having the same letters are not significantly different according to Duncan's New Multiple Range t-Test at $5 \%$ level.

Table 6. Effect of growth medium treatments on pigments contents and total soluble sugars percentage in the leaves of Dracaena umbraculifera plant.

\begin{tabular}{lccc}
\hline \multicolumn{1}{c}{ Treatments } & $\begin{array}{c}\text { Total chlorophyll } \\
\text { content (mg/g f.w.) }\end{array}$ & $\begin{array}{c}\text { Carotenoids } \\
\text { content } \\
(\mathbf{m g} / \mathbf{g} \text { f.w.) }\end{array}$ & $\begin{array}{c}\text { Total soluble } \\
\text { sugars (\%) }\end{array}$ \\
\hline $\begin{array}{l}\text { Peat moss only } \\
\text { Peat moss + sand mixture (1:1, } \\
\text { v/v) }\end{array}$ & $0.737 \mathrm{a}$ & $0.280 \mathrm{a}$ & $9.91 \mathrm{a}$ \\
\hline
\end{tabular}

Means within a column having the same letters are not significantly different according to Duncan's New Multiple Range t-Test at $5 \%$ level.

respectively), while the lowest values in this respect was found in plants grown on peat moss + sand mixture $(1: 1, \mathrm{v} / \mathrm{v})$ as recorded $0.567,0.146$ and $7.50 \mathrm{mg} / \mathrm{g}$ f.w., respectively.

El-Shamy et al. (2009) found that plantlets of Gerbera jamesonii cv. aurantiaca exhibited $100 \%$ survival in plastic pots filled with peat moss and sand at a ratio of $1: 1,2: 1$ and $3: 1$ (by volume). Aslam et al. (2013) on Dracaena sanderiana declared that $50 \%$ of the shoots were also directly rooted as micro-cuttings on soil rite, sand and peat mixture $(1: 1: 1)$. Khafagy et al. (2013) found that on Amphilophium paniculatum, during acclimatization stage, a mixture of sand + peat + perlite at equal parts $(\mathrm{v} / \mathrm{v} / \mathrm{v})$ was used as a potting medium. Juras et al. (2019) on Cattleya xanthina showed that most successful acclimatization was obtained when a mixture of sphagnum and Pinus bark was used as the substrate.

According to the abovementioned results, it is recommended to grow Dracaena umbraculifera plants in peat moss only to get the best growth with high quality.

\section{REFERENCES}

Abd Alla, Neama A.; Ragab, M.E.; ElMiniawy, S.M. and Taha, H.S. (2013). In vitro studies on cassava plant micropropagation of cassava (Manihot esculenta Crantz). Journal of Applied Sciences Research, 9(1):811-820.

Alawaadh, Asma A.; Dewir, Y.H.; Alwihibi, Mona S.; Aldubai, A.A.; El-Hendawy, S. and Naidoo, Y. (2020). Micropropagation of lacy tree philodendron (Philodendron bipinnatifidum Schott ex Endl.). HortScience, 55(3):294-299.

Aslam, J.; Abdul, M. and Sharma, M.P. (2013). In vitro micropropagation of Dracaena sanderiana Sander ex Mast: An important indoor ornamental plant. Saudia J. Biol. Sci., 20(1):63-68.

Bakheet, G.I.A.; Soliman, S.S.; Abdelkader, M.A.I. and Elashtokhy, M.M.A. (2018). Effects of different croton (Codiaeum variegatum L.) genotypes and growth 


\section{A.W. Sayed}

regulators on callus induction, micropropagation and antibacterial activities. Zagazig J. Agric. Res., 45(1):331-347.

Bailey, L.H. (1933). Standard Cyclopedia of Horticulture; Volume I. Macmillan Publishing Co., London, 1070 p.

Chen, Y.; Chen, X.; Hu, F.; Yang, H.; Yue, L., Trigiano, R.N. and Cheng, Z. (2014). Micropropagation of Agave americana. Amer. Soc. Hort. Sci., 49(3):320-327.

Dar, C.T.; Abdullah, Janna O.; Namasivayam, P. and Roowi, S.H. (2012). Sterilization of Hibiscus rosasinensis L. vegetative explants sourced from plants grown in open environment and influences of organic ingredients on In Vitro direct regeneration. Amer. J. Plant. Sci., 3:791-798.

Dave's Garden (2008). Dracaena species: Dracaena umbraculifera. https:// davesgarden.com/guides/pf/go/105018/D racaena umbraculifera.

Dewir, Y.H.; Aldubai, A.A.; El-Hendawy, S.; Alsadon, A.A.; Seliem, Mayada K. and Naidoo, Y. (2018). Micropropagation of Buttonwood tree (Conocarpus erectus) through axillary shoot proliferation. Amer. Soc. Hort. Sci., 53(5):687-691.

Dewir, Y.H.; Aldubai, A.A.; Al-Obeed, R.S.; El-Hendawy, S.; Seliem, Mayada K. and Al-Harbi, Khadija R. (2019). Micropropagation to conserve the endangered Gabal Elba dragon tree (Dracaena ombet Heuglin ex Kotschy \& Peyr). HortScience, 54(1):162-166.

Dodds, J.H. and Roberts, L.W. (1995). Experiments in Plant Tissue Culture; $3^{\text {rd }}$ Ed. Press Syndicate of the Univ. of Cambridge, 276 p.

Dubois, M.; Smith, F.; Illes, K.A.; Hamilton, J.K. and Rebers, P.A. (1956). Colorimetric for determination of sugars and related substances. Ann. Chem., 28(3):350-356.
Edwards, Christine E.; Bassüner, B.; Birkinshaw, C.; Camara, C.; Lehavana, A.; Lowry, P.P.; Miller, J.S.; Wyatt, A. and Jackson, P.W. (2018). A botanical mystery solved by phylogenetic analysis of botanical garden collections: the rediscovery of the presumed-extinct Dracaena umbraculifera. Journal of Oryx, 52 (3): 427-436.

El-Afry, M.M.; Nofal, E.S.; Saadawy, F.M. and Omera, G.A.M. (2017). Tissue culture studies on propagation of some ornamental plants; 1. Starting and shooting stages of Phytolacca dioica L. Journal of Plant Production, Mansoura Univ., 8 (1):27- 32.

El-Shamy, M.A.; Abdel-Sattar, M.M and ElFouly, Amal S.A. (2009). Studies on Gerbera jamesonii Bolus cv. Aurantiaca under micropropagation condition. J. Agric. Sci., Mansoura Univ., 34(3):19391951.

Ghareeb, Fawzia Z. and Taha, Lobna S. (2018). Micropropagation protocol for Antigonon leptopus an important ornamental and medicinal plant. J. Genetic Eng. Biotech., 16(2):669-675.

Hassan, H.M.S. and Moubarak, M. (2020). Micropropagation of yucca plant by using guar and locust bean seed powder as an alternative cheap gelling agent. Sci. J. of Flowers and Ornamental Plants, 7(3):239-246.

James, Byng W.; Chase, M.W.; Christenhusz, M.J.M.; Fay, M.F.; Judd, W.S.; Mabberley, D.J.; Sennikov, A.N.; Soltis, D.E.; Sennikov, A.N.; Soltis, D.E.; Soltis, Pamela S. and Stevens, P.F. (2016). An update of the angiosperm phylogeny group classification for the orders and families of flowering plants: APG IV. Botanical Journal of the Linnean Society, 181:1-20.

Juras, M.C.R.; Jorge, J.; Pescador, R.; Ferreira, W.M.; Tamaki, V. and Suzuki, R.M. (2019). In vitro culture and acclimatization of Cattleya xanthina (Orchidaceae), an endangered orchid of 
the Brazilian Atlantic Rainforest. Rodriguésia, 70:1-11.

Khafagy, M.A.; Saadawy, F.M.; Abo ElKheer, A.M. and Sayed, A.W. (2013). Studies on propagation of some ornamental plants by tissue culture technique; I. Amphilophium paniculatum (L.) Kunth sterilization and multiplication. J. Boil. Chem. Environ. Sci., 8(4):209-231.

Kikowska, M.; Thiem, Barbara; Sliwinska, E.; Rewers, Monika; Kowalczyk, M.; Stochmal, Anna and Oleszek, W. (2014). The Effect of nutritional factors and plant growth regulators on micropropagation and production of phenolic acids and saponins from plantlets and adventitious root cultures of Eryngium maritimum L. J. Plant Growth Regul., 33:809-819.

Kirika, M.W.; Kahia, J.W.; Diby, L.N.; Njagi, E.M.; Dadjo, C. and Kouame, C. (2015). Micropropagation of an endangered medicinal and indigenous multipurpose tree species: Erythrina abyssinica. Amer. Soc. Hort. Sci., 50(5):738-743.

Lizarraga, R.; Tovar P.; Jayasinghe, U. and Dodds, J. (1986). Tissue Culture for Elimination of Pathogens; Specialized Technology Document 3. International Potato Center, Lima, Peru, 22 p.

Mead, R.; Curnow, R.N. and Harted, A.M. (1993). Statistical Methods in Agriculture and Experimental Biology; $2^{\text {nd }}$ Ed. Chapman \& Hall Ltd., London, 335 p.

Murashige, T. and Skoog, F. (1962). A revised medium for rapid growth and bio-assays with tobacco tissue cultures. Physiol. Plant., 15:473-497.

Omira, G.A.M. (2011). Physiological Studies on Micropropagation of Anthurium andraeanum. MSc. Thesis, Fac. Agric., Cairo Univ., Egypt, 143 p.

Prasanth, M. and Sekar, K. (2004). Studies on the age of explant on callus induction in gerbera cv. Mammut. ScientificHorticulture, 9:207-211.
Sagripanti, J. and Bonifacino, A. (1999). Bacterial spores survive treatment with commercial sterilants and disinfectants. Appl. Environ. Microbiol., 65(9):42554260.

Sakr, Salwa S.; Melad, S.S.; El-Shamy, M.A. and Abd El-Hafez, A.E. (2011). Propagation of Cerbera odollam plant by using tissue culture technique. J. Hort. Sci. \& Ornam. Plants, 3(3):276-282.

Sarhan, A.M.Z.; Saadawy, F.M.; Heikal, Amaal A.M. and Abdel Kareem, K.M. (2017). Propagation of the rare ornamental climber Porana paniculata by tissue culture. Scientific J. Flowers and Ornamental Plants, 4(3):259-272.

SAS Institute (2009). SAS/STAT User's Guides Statistics. Vers. 6.04, $4^{\text {th }}$ Ed., SAS Institute, Inc., Cary, N.C., USA.

Sayed, A.W.; Khafagy, M.A.; Abo El-Kheer, A.M and Saadawy, F.M. (2009). Effect of cytokinin type and concentration on the multiplication rate of some ornamental plants. J. Agric. Sci. Mansoura Univ., 34(6): 6689-6698.

Sharifkhani, A.; Saud, H.M. and Aziz, M.B.A. (2011). An alternative safer sterilization method for explants of Aloe vera barbadensis Mill. $2^{\text {nd }}$ International Conference on Chemical Engineering and Applications, Singapore, 23: 32-36.

Silveira, S.S.; Cordeiro, Silva R.; Degenhardt-Goldbach, J. and Quoirin, M. (2016). Micropropagation of Calophyllum brasiliense (Cambess.) from nodal segments. Braz. J. Biol., 76(3):656-663.

Silvestri, C.; Sabbatini, G.; Marangelli, F.; Rugini, E. and Cristofori, V. (2018). Micropropagation and ex vitro rooting of Wolfberry. HortScience, 53(10):14941499.

Steel, R.G.D. and Torrie, J.H. (1980). Principles and Procedures of Statistics. McGrow Hill Book Co., Inc., New York, USA. 633 p. 


\section{A.W. Sayed}

Sumanta, N.; Haque, C.I.; Nishika, J. and Suprakash, $\mathrm{R}$. (2014). Spectrophotometric analysis of chlorophyllous and carotenoids from commonly grown fern species by using various extracting solvents. Res. J. Chem. Sci., 4(9):63-69.

Taha, Lobna S.; Sayed, Sawsan S.; Farahat, M.M. and El-Sayed, Iman M. (2018). In vitro culture and bulblets induction of Asiatic Hybrid Lily 'Red Alert'. J. Biol. Sci., 18(2):84-91.

Tawfik, Azza A.; Ibrahim, O.H.M. and Taha, Mona A. (2020). Micropropagation of Koelreuteria bipinnata using juvenile and mature explants. Current Applied Science and Technology, 20(3):470-478.

Tawfik, Azza A.; Ibrahim, O.H.M.; AbdulHafeez, E.Y. and Ibrahim, Samar A.I.
(2018). Optimizing micropropagation protocol for Rosa hybrida cv. Eiffel Tower with improved in vitro rooting ability. Egypt. J. Hort., 45(2): 323 -335.

Tyagi, H. and Tomar, U.K. (2013). Factors affecting in vitro shoot proliferation and rooting of mature Tecomella undulata (Sm.) Seem tree. Res. Plant Sci., 1(2):3844.

Warakagoda, P.S.; Subasinghe, S.; Kumari, D.L.C. and Neththikumara, T.S. (2007). Micropropagation of sugarcane (Saccharum officinarum L.) through axillary buds. Proceedings of the Fourth Academic Sessions, University of Ruhuna, Sri Lanka, pp. 55-60.

\section{إكثار نبات دراسينا أومبر اكوليفيرا (Dracaena umbraculifera) بواسطة تكنيك زراعة الأنسجة}

$$
\text { قسم بحوث الزينة وتتسيق الحدائق، معهد بحوث البساتين، مركز البحوث الزراعية، الجيزة، مصر }
$$

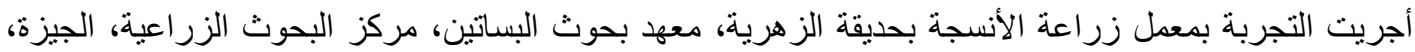

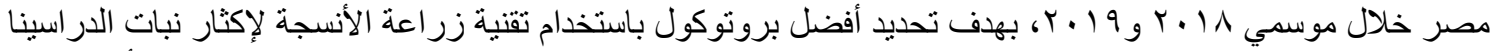
جracaena umbraculifera

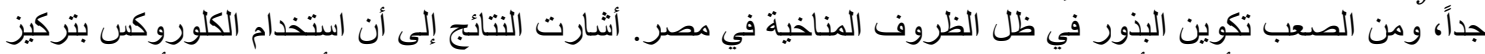

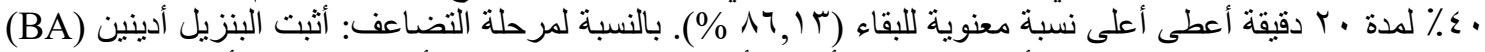

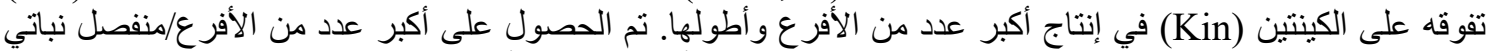

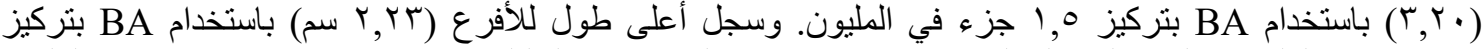

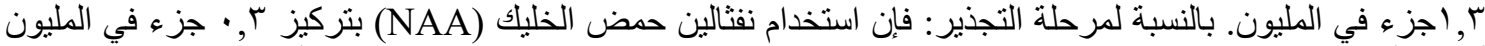

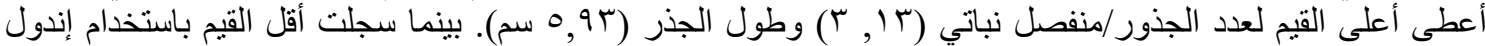

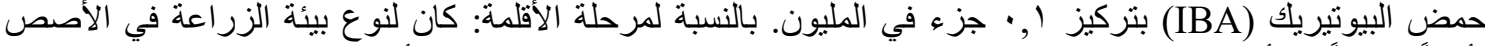

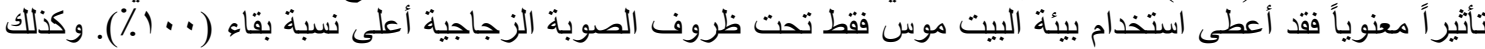

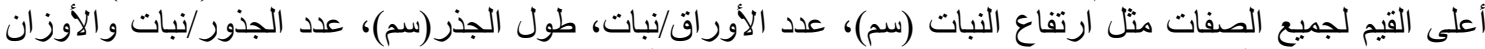

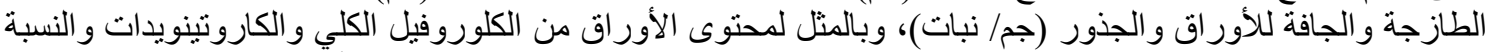

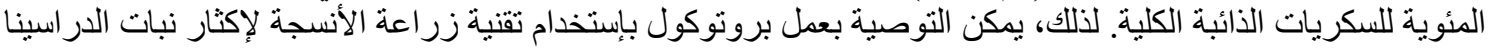
Dracaena umbraculifer

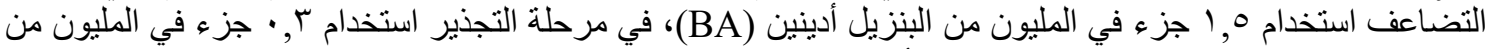

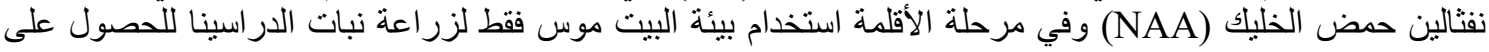

